\title{
PENGARUHROE, EPS DANLEVERAGE TERHADAP HARGA SAHAM PADA INDUSTRI PROPERTI DAN REAL ESTATE DI BEI 2012-2016
}

\author{
RISKA SIREGAR \\ MUSLIMIN \\ MUH.FAISAL \\ Program Studi S1 Manajemen, Fakultas Ekonomi, Universitas Tadulako \\ Email: riskasiregar30@gmail.com,muslimin hasan@gmail.com, faisal@gmail.com
}

\begin{abstract}
This research is to find out and analyze: (1) the effect of Return On Equity, Earning Per Share and Leverage simultaneously affect the stock price in the property and real estate industries in the Indonesian stock exchange, (2) the positive and negative effects of Return On Equity are partially influential on stock prices in the property and real estate industries in the Indonesia Stock Exchange, (3) the positive and negative effects of Earning Per Share partially affect the stock price in the property and real estate industries on the Indonesia Stock Exchange, (4) positive and negative leverage partial effect on stock prices in the property and real estate industry on the Indonesia Stock Exchange.

The type of research used is quantitative. The sampling technique in this study uses purposive sampling, with a sample of 21 companies. Analysis method using panel data regression analysis. The results showed that (1) the effect of Return On Equity, Earning Per Share and Leverage simultaneously on stock prices in the property and real estate industries on the Indonesia Stock Exchange, (2) There was a negative influence on Return On Equity on stock prices in the property industry and real estate on the Indonesia Stock Exchange, (3) There is an effect of Earning Per Share on stock prices on the property and real estate industries on the Indonesia Stock Exchange, (4) No leverage on stock prices in the property and real estate industries on the Indonesia Stock Exchange
\end{abstract}

Keywords: Return On Equity (ROE), Earning Per Share (EPS), Leverage, and Stock Prices

\section{ABSTRACT}

Penelitian ini untuk mengetahui dan menganalisa: (1) pengaruh Return On Equity, Earning Per Sharedan Leverage secara simultan berpengaruh terhadap harga saham pada industri property dan real estate di bursa efek Indonesia, (2) pengaruh positif dan negatif Return On Equitysecara parsial berpengaruh terhadap harga saham pada industri property dan real estate di Bursa Efek Indonesia, (3) pengaruh positif dan negatif Earning Per Share secara parsial berpengaruh terhadap harga saham pada industri property dan real estate di Bursa Efek Indonesia, (4) pengaruh positif dan negatif Leveragesecara parsial berpengaruh terhadap harga saham pada industri property dan real estate di Bursa Efek Indonesia.

Jenis penelitian yang digunakan adalah kuantitatif.Teknik penarikan sampel dalam penelitian ini menggunakan purposive sampling, dengan jumlah sampel 21 perusahaan. Metode analisis menggunakan analisis regresi data panel. Hasil penelitian menunjukkan bahwa (1) pengaruh Return On Equity, Earning Per Share dan Leverage secara serempak terhadap harga saham pada industri property dan real estate di Bursa Efek Indonesia, (2) Terdapat pengaruh Return On Equity secara negatif terhadap harga saham pada industri property dan real estate di Bursa Efek Indonesia, (3) Terdapat pengaruh Earning Per Share terhadap harga saham pada industri property dan real estate di Bursa Efek Indonesia, (4) Tidak berpengaruh Leverage terhadap harga saham pada industri property dan real estate di Bursa Efek Indonesia

Kata Kunci: Return On Equity (ROE), Earning Per Share (EPS), Leverage, dan Harga Saham 


\section{PENDAHULUAN}

Mengukur perkembangan sebuah negara sering kali pertumbuhan ekonomi dijadikan tolak ukur sehingga menyebabkan semua negara berusaha memperkuat diri khususnya dari segi ekonomi. Ketidakstabilan yang signifikan pada perekonomian di dunia saat ini menyebabkan pertumbuhan perekonomian di berbagai negara bahkan dunia mengalami kenaikan serta penurunan perekonomian yang tidak stabil. Sejak tahun 2010 sampai 2012 perekonomian di Indonesia mengalami pertumbuhan sekitar 6\%, dengan rincian pertahun yaitu 2010 sebesar 6,1\%, 2011 dan 2012 sebesar 6,2\%, dan untuk 2013 sebesar 5,8\%, dengan kata lain terjadi penurunan sebesar 0,4\% dai tahun 2012, kemudian pada tahun 2014 sebesar 5,0\% dengan kata lain terjadi peningkatan kembali sebesar 0,8\% dari tahun 2013, (Bank Indonesia, 2015). Sektor yang dapat mempengaruhi pertumbuhan perekonomian yaitu di sektor property, seperti yang ditunjukan pada Bursa Efek Indonesia tentang pertumbuhan perekonomian yang dipengaruhi oleh semua sektor. Pada tahun 2012 pertumbuhan pada sektor property sebesar 60,11\%. Kemudian pada tahun 2013 terjadi penurunan sebesar 22,26\%, kemudian terjadi peningkatan kembali pada tahun 2014 yaitu sebesar 55,76\% (IDX annually, 2012-2014). Pada tahun 2012-2013 pertumbuhan ekonomi pada sektor property mengalami perkembangan yang cukup pesat, jika dilihat dari Bursa Efek Indonesia (BEI) terdapat 50 perusahaan yang kemudian meningkat menjadi 54 perusahaan, kemudian diakhir tahun 2017 terdapat 61 perusahaan yang telah terdaftar. Jika dilihat dari pertumbuhan perekonomian khusus pada sektor property terjadi peningkatan profitabilitas pada perusahaan. Dengan meningkatnya profibilitas perusahaan maka dapat memperpanjang hidup dari perusahaan tersebut, dan tentunya akan berpengaruh pada saham pada perusahaan-perusaan property dan real estate. Industri properti sangat mempengaruhi roda perekonomian dalam negeri tidak heran properti menjadi salah satu sektor bisnis yang diperhatikan oleh pemerintah.

Investor tentunya mengharapkan keuntungan dari investasinya. Perkembangan investasi pada suatu industri tentunya akan tergambar dari harga-harga saham industri tersebut. Berinvestasi khususnya pada industri properti dan real estate ada berbagai hal yang mempengaruhi perubahan harga saham. Hal tersebut tentunya harus perhitungkan agar terhindar dari risiko yang mungkin saja terjadi. Menurut Gitman (2012:81) setia laba perusahaan per aham (EPS) secara umum dapat menarik perhatian bagi para pemegang saham dan manajemen seperti yang dicatat sebelumnya, EPS merupakan jumlah dolar yang diperoleh selama periode berjalan atas nama masing-masing saham terhutang dari semua saham yang telah beredar. Earning Per Share (EPS) atau laba setiap lembarnya dapat menunjukkan seberapa besar keuntungan perusahaan yang selanjutnya siap di berikan bagi semua pemegang saham, maka perusahaan akan mendapatkan keuntungan ketika harga saham meningkat.

\section{KAJIAN LITERATUR DAN PENGEMBANGAN HIPOTESIS}

Menurut Horne dan Wachowicz Jr. (2012:2), "Manajemen keuangan berkaitan dengan perolehan aset, pendanaan, dan manajemen aset dengan didasari beberapa tujuan umum". Menurut Agus dan Martono (2013:4), "manajemen keuangan yaitu segala aktivitas perusahaan yang berkaitan dalam mendapatkan dana, menggunakan dana serta pengelolaan aset sesuai tujuan dari perusahaan".

Rasio Keuangan atau Financial Ratioadalah alat dalam menganalisis keuangan dan kinerja perusahaan berdasarkan data keuangan yang diperoleh dari pos laporan keuangan (neraca, laporan laba/rugi, laporan aliran kas). Menurut Fahmi (2012:107) rasio dapat diartikan sebagai bahan kajian untuk dianalisis dan diputuskan berdasarkan perbandingan dari jumlah satu dengan jumlah lainnya dan akan dilihat hasil dari suatu jawaban perbandingan tersebut. Rasio keuangan Horne dan Wachowicz Jr (2012:163) adalah indeks 
yang menghubungkan dua angka akuntansi dan didapat dengan membagi suatu angka dengan angka lain. Menurut Kasmir (2012:104) kegiatan membandingkan angka-angka pada laporan keuangan dengan cara membagi satu angka dengan angka lainnya merupakan rasio keuangan. Laporan keuangan dilakukan melalui perbandingan dari satu komponen dengan komponen yang lain.

Salah satu faktor dari dua faktor penting evaluasi yaitu pertimbangan ketika terjadi investasi saham yaitu harga saham. Faktor yang lain yaitu nilai dari perusahaan (Sentioso 2014:7). Darmadji dan Fakhrudin (2012:102) pada waktu tertentu harga saham terjadi di bursa yang dapat berubah setiap waktu dengan cepat baik itu naik maupun turun. Harga saham bisa berubah dari hitungan menit bahkan dalam hitungan detik. Hal tersebut diakibatkan banyaknya permintaan dan penawaran diantara pembeli saham dan penjual saham.Sedangkan, menurut Sri Ratna Hadi (2013:179) Harga saham adalah nilai saham dalam rupiah yang terbentuk akibat terjadinya aksi pembelian dan penawaran saham di bursa efek oleh sesame anggota bursa

Harga saham menunjukkan seberapa baik manajemen menjalankan tugasnya atas nama para pemegang saham. Menurut Harmono (2016:50)nilai harga saham di pasar dapat diukur melalui nilai perusahaan berdasarkan harga saham yang sudah terbentuk pada perusahaan di pasar yang menjadi penilaian dari publik terhadap kinerja pada perusahaan secara rill.

Kasmir (2013:204)rasio untuk mengukur laba bersih sesudah pajak dengan modal sendiri merupakan hasil pengembangan ekuitas atau return on equity atau rentabilitas modal sendiri. Efisiensi penggunaan modal sendiri dapat ditunjukan melalui rasio ini. Tingkat rasio dapat dikatakan semakin baik jika rasio ini tinggi. Demikian juga sebaliknya apabila rasio tersebut rendah maka posisi pemilik perusahaan semakin lemah. Menurut Hanafi dan Halim (2012:82) Return on Equity (ROE), dalam mengukur kemampuan perusahaan dalam mendapatkan keuntungan yang berdasarkan modal saham tertentu dapat dilihat dari rasio ini.

Menurut Gitman (2012:81) pengertian Earning Per Share (EPS), yaitu "The firm's earnings per share (EPS) is generally of interest to present or prospective stockholders and management. As we noted earlier, EPS represents the number of dollars earned during the period on behalf of each outstanding share of common stock." Darmadji dan Fakhruddin (2012:54) "Rasio yang yang menunjukkan bagian laba untuk setiap saham. EPS menggambarkan profitabilitas perusahaan yang tergambar pada setiap lembar saham." Jika laba per saham lebih tinggi, maka prospek perusahaan lebih baik, sementara jika laba per saham lebih rendah berarti kurang baik, dan laba per saham negatif berarti tidak baik.

EPS atau pendapatan per lembar saham merupakan keuntungan yang diberikan pada pemegng saham dari setiap lembar saham yang dimiliki (Fahmi, 2012:97). Earning Per Share merupakan tingkat kemampuan dari suatu perusahaan menghasilkan keuntungan per lembar saham (Sutrisno, 2012:223). Semakin besar EPS akan menunjukkan bahwa keuntungan yang diperoleh perusahaan semakin bertambah. Untuk investor informasi tentang EPS adalah informasi yang paling dasar dan mempunyai fungsi yang sangat penting karena dapat sebaga gambaran perubahan earning dimasa yang akan datang.

Menurut Hanafi dan Halim (2012:75), menjelaskan Rasio leverage merupakan rasio yang mengukur kemampuan perusahaan untuk memenuhi kewajiban-kewajiban jangka panjangnya.Menurut Reeve et al (2014:174), menjelaskan mengenai leverage sebagai berikut "Leverage isusing debt to increase the return on an investment".

Menurut Fahmi (2012) rasio leverage adalah rasio yang dapat menghitung jumlah utang yang sudah membiayai suatu perusahaan.Menurut Fred Weston dalam buku Kasmir (2012:151), rasio yang mengukur suatu aktiva perusahaan dibiayai dengan utang adalah rasio solvabilitas atau leverage. Syamsudin 
(2009)leverage adalah rasio hubungan pinjaman jangka panjang yang dapat ditunjukkan dan diberikan oleh kreditur berupa modal sendiri yang diberikan oleh pemilik perusahaan.

\section{METODE PENELITIAN}

Penelitian ini menggunakan metode deksriptif yang bersifat kuantitatif karena objek penelitian yang digunakan pada perusahaan data suatu industri dengan waktu tertentu dengan cara melakukan pengumpulan data serta semua yang informasi dari perusahaan yang sesuai dengan data yang dibuuhkan untuk penelitian. Metode ini dikatakan sebagai metode penelitian kuantitatif dikarenakan pada penelitian ini alat analisis yang digunakan yaitu statistik dan hasil penelitiannya berupa angka (Sugiyono, 2013:7). Adapun tujuan dari penelitian ini adalah untuk dapat mengetaahui pengaruh dari Return On Equity (REO), Earning Per Share (EPS), dan Leverage terhadap harga saham pada industri properti yang sudah terdaftar pada Bursa Efek Indonesia.

Berdasarkan permasalahan dan hipotesis yang akan diuji, adapun data yang digunakan yaitu data sekunder yang diperoleh dari pihak tertentu dalam bentuk data yang sudah jadi atau berupa publikasi. Sumber data sekunder adalah data yang tidak diberikan lansung kepada pengumpul data atau peneliti, seperti misalnya data diperoleh dari orang lain ataupun lewat dokumen (Sugiyono, 2013:137). Pada umumnya data sekunder berupa data yang berbentuk catatan atau laporan yang telah disusun dalam arsip yang telah atau belum dipublikasi, struktur organisasi ketenagakerjaan dan laporan keuangan.

Data keuangan yang penulis gunakan adalah data sekunder berupa data kurun waktu perusahaanproperty dan real state selama lima tahun dari 2012-2016 yang bersumber dari laporan keuangan yang diterbitkan di Bursa Efek Indonesia melalui website www.idx.co.id.

Populasi dan Teknik Penarikan Sampel

Populasi merupakan wilaya yng terdiri dari subjek/objek yang memiliki kemampuan atau kemungkinan yang dapat membantu dalam proses pengumpulan data yang kemudian ditarik kesimpulan (sugiono,2014:148). Dlam penelitian ini populasi yang digunakan yaitu semua perusahaan industri properti yang telah terdaftar pada Bursa Efek Indonesia. Adapun jumlah industri properti yang tellah terdaftar pada Bursa Efek Indonesia yaitu 61 perusahaan.

Sampel adalah bagian dari jumlah dan karakterisktik yang dimiliki oleh populasi tersebut (Sugiyono,2014:149). Teknik pengambilan sampel dalam penelitian ini adalah dengan metode purposive sampling. Menurut Sugiyono (2013:122) purposive sampling adalah Teknik penentuan sampel dengan prtimbangan tertentu. Jumlah perusahaan property dan real estate yang terdaftar di Bursa Efek Indonesia menjadi sampel sebanyak 23 perusahaan. pemelihan sampel penelitian ini ditentukan berdasarkan kriteria yang telah ditetapkan, yaitu sampel ditarik sejumlah tertentu dari populasi emitmen dengan menggunkan pertimbangan atau kreteria tertentu. Daftar perusahaan yang termasuk dalam penelitian ini dapat dilihat dalam tabel 1 sebagai berikut:

Metode pengumpulan data pada penelitian ini disesuaikan dengan jenis data yang digunakan, karena jenis data pada penelitian ini yaitu data sekunder maka metode pengumpulan data yang digunakan yaitu metode dokumentasi yang sering disebut juga dengan metode arsip (archival research). Metode Dokumentasi adalah metode pengumpulan data dengan menggunakan konsep-konsep atau teori yang dapat dipakai dalam pembahasan masalah penelitian, meliputi dokumen-dokumen dan jurnal. Metode dokumentasi dalam penelitian ini menggunakan data yang tersedia dalam laporan tahunan perusahaan 
properti dan real state tahun 2012-2016 melalui situs yang dimiliki oleh Bursa Efek Indonesia, yakni www.idx.co.id.

\section{HASIL DAN PEMBAHASAN}

\section{Analisis Data Panel}

Penelitian ini menggunakan variabel Return On Equity,Earning Per Sharedan Leveragesebagai variabel independen dan Harga Saham sebagai variabel dependen.Hipotesis pertama menyatakan bahwa variabel independen mempunyai pengaruh secara serempak terhadap variabel dependen pada perusahaan Properti dan Real Estate di Bursa Efek Indonesia. Sementara hipotesis kedua sampai keempat menyatakan variabel independen mempunyai pengaruh secara parsial terhadap variabel dependen.

Guna membuktikan hipotesis yang dikemukakan pada penelitian ini maka digunakan alat analisis yaitu regresi data panel untuk melihat pengaruh dari Earning Per Share, Return On Equity dan Leverage pada harga saham perusahaan properti yang telah terdaftar pada Bursa Efek Indonesia.

Hasil perhitungan regresi data panel dari penelitian ini dapat dilihat pada tabel 4 berikut ini:

\section{Tabel1.Hasil Regresi Data Panel}

Dependent Variable: HARGASAHAM?

Method: Pooled Least Squares

Included observations: 5

Cross-sections included: 21

Total pool (balanced) observations: 105

\begin{tabular}{|c|c|c|c|c|}
\hline Variable & Coefficient & Std. Error & t-Statistic & Prob. \\
\hline $\mathrm{C}$ & 96.11530 & 154.5491 & 0.621908 & 0.5357 \\
\hline ROE? & -2283.428 & 612.9320 & -3.725418 & 0.0004 \\
\hline EPS? & 8.964463 & 0.710979 & 12.60862 & 0.0000 \\
\hline LEVERAGE? & 185.5021 & 98.19845 & 1.889053 & 0.0625 \\
\hline \multicolumn{5}{|c|}{ Effects Specification } \\
\hline \multicolumn{5}{|c|}{ Cross-section fixed (dummy variables) } \\
\hline R-squared & 0.935457 & \multicolumn{2}{|c|}{ Mean dependent var } & 1338.784 \\
\hline Adjusted R-squared & 0.917130 & \multicolumn{2}{|c|}{ S.D. dependent var } & 1959.180 \\
\hline S.E. of regression & 563.9931 & \multicolumn{2}{|c|}{ Akaike info criterion } & 15.70559 \\
\hline Sum squared resid & 25765143 & \multicolumn{2}{|c|}{ Schwarz criterion } & 16.31221 \\
\hline Log likelihood & -800.5436 & \multicolumn{2}{|c|}{ Hannan-Quinn criter. } & 15.95141 \\
\hline F-statistic & 51.04233 & \multicolumn{2}{|c|}{ Durbin-Watson stat } & 2.112025 \\
\hline $\operatorname{Prob}($ F-statistic) & 0.000000 & & & \\
\hline
\end{tabular}

Sumber: Hasil output regresi panel data eviews 7

Berdasarkan hasil perhitungan pada tabel 4 dapat dirumuskan persamaanregresi data panel dari penelitian ini sebagai berikut: 


\section{$Y=96,115+-2283.428\left(X_{1}\right)+\mathbf{8 . 9 6 4}\left(X_{2}\right)+\mathbf{1 8 5 . 5 0 2}\left(X_{3}\right)$}

Besarnya nilai konstanta adalah 96,115, menunjukkan bahwa bila return on equity, earning per share dan leverage dianggap tidak berpengaruh maka harga saham akan bernilai bernilai positif.

VariabelReturn On Equity $\left(\mathrm{X}_{1}\right)$ mempunyai koefisien sebesar -2283,428, hal ini berarti setiap perubahan positif variabel $\mathrm{X}_{1}$, maka akan menurunkan harga saham. Variabel Earning Per Share $\left(\mathrm{X}_{2}\right)$ mempunyai koefisien sebesar 8,964, hal ini berarti setiap perubahan variabel $\mathrm{X}_{2}$ sebesar 1 poin, harga saham akan meningkat sebesar 8,964. Variabel Leverage $\left(\mathrm{X}_{3}\right)$ mempunyai koefisien sebesar 185,502, hal ini berarti setiap perubahan variabel $\mathrm{X}_{3}$ sebesar 1 poin akan meningkatkan harga saham sebesar 185,5021.

\section{Pengujian Hipotesis}

\section{Uji Secara serempak (Uji F)}

Kriteria pengujian hipotesis yang pertama dalam penelitian ini adalah dengan membandingkan $\mathrm{F}_{\text {hitung }}$ $(51.04233)>\mathrm{F}_{\text {tabel }}(2,46)$ dengan taraf signifikan $(0,000<0,05)$ maka kesimpulannya $\mathrm{H}_{0}$ ditolak dan $\mathrm{H}_{1}$ diterima. Dapat diartikan bahwa seluruh variabel independen yang digunakan pada penelitian ini yang dikategorikan kedalam model penelitian secara simultan atau serempak berpengaruh signifikan terhadap variabel dependen. Maka dari pernyataan diatas disimpulkan bahwa dalam penelitian ini hipotesis pertama yang menyatakan seluruh variabel independen yang digunakan dalam penelitian ini memiliki pengaruh yang signifikan terhadap variabel dependen pada perusahaan properti yang telah terdaftar pada Bursa Efek Indonesia dapat diterima kebenarannya atau dapat dibuktikan.

\section{Uji Parsial (Uji t)}

\section{Return On Equity (X1)}

Pengujian tentang berpengaruh atau tidaknya variabel independen terhadap variabel dependen dengan melihat taraf signifikansi dan nilai koefisien. Taraf signifikansi memberikan makna variabel independen (X1) berpengaruh secara signifikan terhadap variabel dependen (Y) sedangkan nilai koefisien memberikan makna bahwa pengaruh yang diberikan variable (X1) terhadap variabel dependen (Y) berpengaruh negatif. Maka dari pernyataan diatas disimpulkan bahwa hipotesis kedua yang menyatakan variabel independen (X1) secara parsial berpengaruh positif dan signifikan terhadap variabel dependen (Y) pada perusahaan properti yang terdaftar pada Bursa Efek Indonesia periode 2012-2016 ditolak atau tidak dapat dibuktikan. Dari hasil penelitian ini dapat dilihat bawha ada pengaruh yang signifikan dari ROE terhadap harga saham adalah negatif.

\section{Earning Per Share (X2)}

Pengujian tentang berpengaruh atau tidaknya variable independen (X2) terhadap variabel dependen (Y) yaitu dengan cara melihat taraf signifikansi dan nilai koefisien.Taraf signifikansi memberikan makna bahwa variabel (X2) memiliki pengaruh yang signifikan terhadap variabel dependen (Y), sedangkan nilai koefisien memberikan makna bahwa pengaruh yang diberikan variabel independen (X2) terhadap variabel dependen (Y) berpengaruh positif. Maka dari pernyataan diatas disimpulkan bahwas hipotesis ketiga yang menyatakan variable variabel independen (X2) secara parsial berpengaruh signifikan dan positif terhadap variabel dependen (Y) pada perusahaan Properti dan Real Estate yang terdaftar di Bursa Efek Indonesia periode 2012-2016 diterima atau dapat dibuktikan.

\section{Leverage (X3)}

Pengujian tentang berpengaruh atau tidaknya variable independen (X3) terhadap variabel dependen (Y) dapat diketahui dengan cara melihat taraf signifikansi dan nilai koefisien. Taraf signifikansi memberikan makna bahwa Leverage tidak berpengaruh secara signifikan terhadap variabel dependen (Y), sedangkan 
nilai koefisien memberikan makna bahwa Leverage memiliki pengaruh yang positif terhadap variabel dependen (Y). Maka dari pernyataan diatas disimpulkan bahwa hipotesis keempat yang menyatakan variable independen (X3) secara parsial berpengaruh signifikan terhadap variabel dependen (Y) pada Perusahaan Properti dan Real Estate di Bursa Efek Indonesia periode 2012-2016 ditolak atau tidak dapat dibuktikan.

\section{Koefisien Determinasi $\left(\mathbf{R}^{2}\right)$}

Nilai koefisien determinasi yang digunakan adalah nilai Adjusted $R$ Square karena penelitian ini menggunakan 3 variabel independen.Hasil perhitungan yang diperoleh besarnya koefisien determinasi yang disesuaikan (Adjusted $R$ Squared) adalah 0,917. Artinya semua variabel independen terhadap perubahan nilai variabel dependen adalah $91,7 \%$ dan sisannya $7,3 \%$ dipengaruh oleh variabel lain selain danvariabel independen yang digunakan dalam regresi data panel seperti manajemen perusahaan, faktor eksternal perusahaan antara lain peraturan pemerintah, tingkat suku bunga, inflasi, nilai tukar rupiah serta keadaan perekonomian yang tidak stabil.

\section{Pembahasan}

Pengaruh Return On Equity,Earning Per Share dan Leverage Terhadap Harga Saham (Uji F) Berdasarkan hasil analisis, diketahui bahwa variabel independen (X1), (X2) dan (X3) secara serempak memiliki pengaruh yang signifikan terhadap variabel dependen (Y) pada perusahaan Properti dan Real Estate. Adapun hasil penelitian ini sesuai dengan penelitian Damayanti et al (2013) yang menyatakan bahwa Earning Per Share, Debt to Equity dan Return On Equity berpengaruh terhadap Harga Saham.

Hasil penelitian ini, dapat dibuktikan bahwa semua variabel yang digunakan dalam penelitian ini yang merupakan contoh rasio keuangan yang mempengaruhi harga saham. Terpengaruhnya harga saham, merupakan bukti jika rasio keuangan memiliki peran dalam tahap pengambilan keputusan bagi investor ketika akan melakukan pembelian atau penjualan saham, karena perubahan harga saham juga akan berubah apabila permintaan dan penawaran juga berubah.

\section{Pengaruh Return On Equity Terhadap Harga Saham}

Dari hasil pengujian regresi data panel yang dilakukan maka dapat disimpulkan jika variabel Berdasarkan hasil pengujian regresi data panel dapat disimpulkan bahwa variabel independen (X1) memiliki pengaruh terhadap variabel dependen (Y) pada Perusahaan Properti dan Real Estate di Bursa Efek Indonesia periode 2012 sampai dengan 2016. Berdasarkan hasil pengujian ditemukan pengaruh negatif signifikan dari nilai Return On Equity (ROE) terhadap harga saham.

Pengaruh negatif roe terhadap harga saham dalam penelitian ini merupakan indikasi bahwa investor tidak tertarik untuk mendapatkan laba jangka panjang akan tetapi lebih tertarik pada laba jangka pendek yaitu capital gain sehingga dalam mempertimbangkan pembelian saham mengikuti trend yang terjadi di pasar, sehingga muncul sentimen negatif akan efisiensi perusahaan dalam menggunakan modal sendiri dalam menghasilkan laba.

\section{Pengaruh Earning Per Share Terhadap Harga Saham}

Dari hasil pengujian regresi data panel yang dilakukan maka dapat disimpulkan jika variabel Berdasarkan hasil pengujian regresi data panel dapat disimpulkan bahwa variabel independen (X2) memiliki pengaruh terhadap variabel dependen (Y) pada Perusahaan Properti dan Real Estate di Bursa Efek Indonesia periode 2012 sampai dengan 2016. Hasil dari uji t yang dilakukan maka dapat diketahui bahwa pengaruh EPS terhadap harga saham memiliki pengaruh yang signifikan. Semakin besar tingkat kemampuan dari 
suatu perusahaan untuk menghasilkan keuntungan perlembar saham bagi pemiliknya maka semakin profitabel dan menarikinvestasi padaperusahaantersebut. Hal ini akan memberikan efek positif padahargasaham(Susilo,2005).

Hasil penelitian ini sesuai dengan penelitian Ratih et al(2013), Saputra et al (2014) dan Ariyanti et al (2016) yang menyatakan bahwa variabel inddependen (X2) memiliki pengaruh yang signifikan terhadap variabel independen (Y) dan mendukung teori signal karena betapa pentingnya informasi yang disediakan suatu perusahaan yang dapat dijadikan pertimbangan untuk pengambilan keputusan investasi oleh pihakpihak eksternal perusahaan. Informasi adalah unsur yang sangat penting bagi para pelaku usaha atau investor, karna informasi yang disediakan pasti menyediakan keterangan, catatan dan dan gambaran yang baik dan keadaan di masa lalu, saat ini dan keadaan masa yang akan dating yang berhubungan dengan kelangsungan hidup dari perusahaan seerta bagimana efek yang akan didapatkan. Para investor di pasar modal sangat membutuhkan informasi yang lengkap, akurat dan relevan yang digunakan sebagai alat analisis untuk pengambilan keputusan ketika akan melakukan investaso.

\section{Pengaruh Leverage Terhadap Harga Saham}

Dari hasil pengujian regresi data panel yang dilakukan maka dapat disimpulkan jika variabel Berdasarkan hasil pengujian regresi data panel dapat disimpulkan bahwa variabel independen (X3) memiliki pengaruh terhadap variabel dependen (Y) pada Perusahaan Properti dan Real Estate di Bursa Efek Indonesia periode 2012 sampai dengan 2016. Berdasarkan hasil pengujian ditemukan pengaruh tidak signifikan darinilai Leverage terhadap harga saham.

Peningkatan resiko kredit yang tumbuh bersama lajunya pertumbuhan sektor property dan real estate menjadi pertimbangan khusus bagi investor untuk membeli saham karena terkait dengan langsung kemampuan perusahaan menjalankan aktivitasnya yang dibiayai dengan utang dalam kondisi ekonomi yang sedang bergejolak. Namun ada beberapa investoryang berkeyakinan bahwa perusahaan yang ingin tumbuh dan berkembang pasti memerlukan hutang yang dijadikan sebagai dana tambahan untuk dijadikan sebagai dna tambahan bagi perusahaan yang tumbuh. Perusahaan yang ingin tumbuh pasti akan memerlukan dana yang besar sebagai dana operasional yang mungkin tidak dapat dipenuhi hanya dengan modal sendiri yang dimiliki oleh perusahaa, kondisi ini menyebabkan kemunkinan berkembangnya perusahaan dimasa yang akan datang yang berujung pada meningkatnya harga saham.

\section{KESIMPULAN DAN SARAN}

\section{Kesimpulan}

Berdasarkan pembahasan hasil penelitian dapat ditarik beberapa kesimpulan sebagai berikut:

1. Secara serempak, Earning Per Share(EPS), Return On Equity (ROE), dan Leverage berpengaruh signifikan terhadap harga saham perusahaan Properti dan Real Estate.

2. Earning Per Share Secara parsial berpengaruh signifikan terhadap harga saham perusahaan Properti dan Real Estate.

3. Return On Equity berpengaruh negatif terhadap harga saham perusahaan Properti dan Real Estate.

4. Leverage tidak berpengaruh terhadap harga saham perusahaan Properti dan Real Estate.

\section{Saran}

Berikut adalah saran-saran yang diajukan berdasarkan hasil penilitian, sebagai berikut: 
1. Earning per share (EPS), return on equity (ROE) dan Leverage perlu menjadi pertimbangan bagi calon investor untuk menambahkan modal pada perusahaan Properti dan Real State. Pada penelitian ini Earning per share (EPS) berpengaruh positif dan paling kuat diantara ketiga rasio (Earning per share (EPS), return on equity (ROE) dan Leverage) terhadap Harga Saham sehingga Earning per share (EPS) yang merupakan laba yang di peroleh untuk tiap lembar saham adalah hal yang paling penting untuk diperhatikan bagi investor.

2. Bagi peneliti selanjutnya, penelitian dapat dilakukan lebih dalam dilakukan lebih mendalam dengan menambah periode penelitian dan tidak hanya terbatas pada perusahaan Properti dan Real State saja. Diharapkan penelitian selanjutnya dilakukan pada semua sektor industri yang terdaftar di Bursa Efek Indonesia dengan menambah variabel yang merupakan faktor internal dan eksternal yang mempengaruhi Harga Saham, karena masih banyak faktor pengaruh yang tidak digunakan dalam penelitian ini.

\section{REFERENSI}

Brigham, Eugene F.dan Joel F Houston. (2014). Dasar-dasar Manajemen Keuangan. Jakarta: Salemba Empat.

Damayanti, Dzulkirom AR dan Azizah.(2013). Pengaruh Earning Per Share, Debt To Equity Ratio Dan Return on equity Terhadap Harga Saham (Studi Pada Sektor Properti dan Real Estate Yang Terdaftar Di BEI Tahun 2009-2011).Jurnal Administrasi Bisnis (JAB)|Vol. 1 No. 2.

Darmadji, T dan Fakhrudin M.H. (2012). Pasar Modal Di Indonesia. Edisi Ketiga. Jakarta: Salemba Empat.

Fahmi, Irham. (2012). Analisis Laporan Keuangan. Bandung:Alfabeta. . (2012). Analisis Laporan Keuangan.Cetakan Ke-2. Bandung: Alfabeta. . (2012). Pengantar Pasar Modal, Cetakan Pertama, Bandung: Alfabeta,

Hanafi, Mamduh dan Abdul Halim. (2012). Analisis Laporan Keuangan. Edisi Ketiga. Cetakan Pertama. Penerbit UPP Sekolah Tinggi Ilmu Manajemen YKPN. Yogyakarta.

Harmono. (2016). Manajemen keuangan. Edisi pertama. Cetakan Ke-5. Jakarta: Bumi aksara.

Horne, James C. Van dan John M Wachowicz, Jr. (2012). Prinsip-prinsip Manajemen Keuangan (Edisi 13).Jakarta: Salemba Empat.

Kasmir. (2012). Analisis Laporan Keuangan. Jakarta:Raja Grafindo. . (2013). Analisis Laporan Keuangan. Jakarta: PT Raja Grafindo Persada.

Nachrowi danUsman (2006). "Ekonometrika untukAnalisis Ekonomi danKeuangan”, Jakarta: Fakultas Ekonomi UniversitasIndonesia.

Martono. (2013).Manajemen Keuangan, Yogyakarta: Ekonisia. 
Reeves, James M, Carls S.Warren \& Jonathan E. Duchac. (2014). Pengantar Akuntansi Adaptasi Indonesia. Buku 2. Jakarta: Salemba Empat.

Ross, Westerfield, Jordan, Lim, dan Tan. (2015). Pengantar keuangan perusahaan. Buku 1. Edisi Global Asia. Jakata: Salemba Empat

Setianto, Buddy. (2014). Investasi Nilai Wajar Saham (Value Investing) Bagaimana Aplikasinya Di Bursa Efek Indonesia. Jakarta: BSK Capital.

Sri Ratna Hadi. (2013). Sukses Membeli Saham Tanpa Modal Secara Otodidak. Jakarta Timur: Laskar Aksara.

Sutrisno. (2012). Manajemen Keuangan Teori, Konsep dan Aplikasi (8th ed.).Yogyakarta: Ekonisia Sugiyono. (2012). Metode Penelitian Kuantitatif Kualitatif dan R\&B. Bandung: Alfabeta. . (2013). Metode Penelitian Manajemen. Bandung: Alfabeta . (2014). Metode Penelitian Kuantitatif, Kualitatif, dan Kombinasi (Mixed Methods).

Bandung: Alfabeta

Syamsuddin. (2009). Manajemen Keuangan Perusahaan. Jakarta: PT. Raja Grafindo Persada.

Widarjono,Agus. (2009).“EkonometrikaPengantardanAplikasinya”, Yogyakarta:EkonisiaFEUII. 